\title{
CELL PHONE TOWER PROXIMITY IMPACTS ON \\ HOUSE PRICES: A NEW ZEALAND CASE STUDY
}

\author{
SANDY BOND \\ Curtin University
}

\section{ABSTRACT}

The siting of cellular phone towers (CPBSs) is of particular public concern due to fears of potential health hazards from the electromagnetic fields (EMFs) that these devices emit. The unsightliness of these structures and fear of lowered property values are other regularly voiced concerns about the siting of CPBs. This paper outlines the results of further research to show the effect that distance to a CPBS has on residential property prices in New Zealand (NZ). The results of this research will be of interest to valuers when valuing properties in close proximity to $C P B S s$ and for determining compensation, if any, to affected property owners.

Keywords: Cellular phone base stations, GIS, market perceptions, multiple regression analysis, property values

\section{INTRODUCTION}

There have been persisting concerns about the possible impact of cellular phones and cellular phone base stations on health due to the electromagnetic fields (EMFs) they emit. This was appreciated by the UK government, which in 1999 took the early initiative of setting up the Independent Expert Group on Mobile Phones (IEGMP) to review the situation. Its report, Mobile Phones and Health (the Stewart Report), published in May 2000, concluded that:

“....it is not possible at present to say that exposure to RF radiation, even at levels below national guidelines, is totally without potential adverse health effects, and that the gaps in knowledge are sufficient to justify a precautionary approach."

The Stewart report concluded a precautionary approach to the use of mobile phone technologies be adopted until much more detailed and scientifically robust information on any health effects becomes available.

Controversy remains about whether or not exposure of humans to electromagnetic fields can cause cancer. Some studies show an association between certain types of cancers and residential exposure to electromagnetic fields generated by radio, cellular phone and television transmitters (see for example, Hardell, Mild \& 
Carlberg, 2003; AGNIR, 2003; Chen et al., 2000; Michelozzi et al., 2002). However, a review of the evidence on cellular phones, cell phones base stations, and brain cancer by Moulder et al. (2005), concludes that "a weight-of-evidence evaluation shows that the current evidence for a causal association between cancer and exposure to RF energy is weak and unconvincing."

Due to the abovementioned controversy, there appears to be ongoing concern about the siting of cellular phone base stations (CPBSs) due to fears of health risks from exposure to EMFs, changes in neighborhood aesthetics and loss in property values. However, the extent to which such attitudes are reflected in lower property values affected by CPBSs is not well understood.

This paper outlines the results of research conducted in 2004 that follows an earlier study carried out in Christchurch, NZ in 2003 to show the effect that proximity to cellular phone base stations (CPBSs) has on residential property values. This current study looks specifically at the impact of distance to a CPBS on residential house prices. It involved the same case study areas in Christchurch city in the South Island of New Zealand as the previous study for comparison purposes. A summary of the results from the previous study are outlined in the literature review.

\section{LITERATURE REVIEW}

\section{Property value effects from CPBSs}

Few studies have been conducted to ascertain the adverse health and visual effects of cell phone towers on property values. Further, as there have been very few cell site cases proceeding to the Environment Court in NZ, only limited evidence of property value effects has been provided by the courts. Thus, the extent to which opposition from property owners affected by the siting of cell phone towers are reflected in lower property values is not widely known in NZ.

Bond and Beamish (2005) review the two studies commissioned by Telecom in Auckland, Whangarei and Hamilton (1998/99) as well as Christchurch (2001). The results of both studies showed that property prices are not statistically significantly affected by the presence of cell phone towers. However, both studies involved only limited sales data analysis. Further, Bond and Beamish suggest that as the sponsoring party to the research was a telecommunication company, it is questionable whether the results are completely free from bias.

Two parallel studies were carried out in Christchurch, NZ by Bond and Beamish (2005) and Bond and Wang (2005) to show the effect that proximity to cellular phone base stations (CPBSs) has on residential property values. The City of Christchurch was selected as the case study area due to the large amount of media attention this area had received in recent years relating to the siting of CPBSs. Two 
prominent court cases over the siting of CPBSs were the main cause for this attention (McIntyre and others vs. Christchurch City Council [1996] NZRMA 289 and Shirley Primary School vs. Telecom Mobile Communications Ltd [1999] NZRMA 66). In summary, the Environmental Court ruled in each case that there is no established adverse health effects arising from the emission of radio waves from CPBSs as there is no epidemiological evidence to show this. However, in the court's decisions, they did concede that while there are no proven health affects that there is evidence of property values being affected by both of the above allegations.

These court cases were only the start of the negative publicity surrounding CPBSs in Christchurch. Dr. Neil Cherry, a prominent and vocal local professor, served only to fuel the negative attention to CPBSs by regularly publishing the health hazards relating to these structures (see Cherry, 2000). This media attention had an impact on the results of the studies, outlined next.

The first study by Bond and Beamish (2005) comprised a postal survey to investigate the perceptions of residents towards living near CPBSs and how this proximity might affect property values. The survey included residents in ten suburbs: five case study areas (within 100 feet of a cell phone tower) and five control areas (over 0.6 of a mile from a cell phone tower). Eighty questionnaires were distributed to each of the ten suburbs in Christchurch (i.e. 800 surveys were delivered in total). An overall response rate of $46 \%$ was achieved.

The results were mixed with responses from residents ranging from having no concerns to being very concerned about proximity to a tower. In both the case study and control areas, the impact of proximity to towers on future property values is the issue of greatest concern for respondents. If purchasing or renting a property near a tower, over a third (38\%) of the control group respondents would reduce price of their property by more than $20 \%$. The perceptions of the case study respondents were less negative with a third of them saying they would reduce price by only $1-9 \%$, and $24 \%$ would reduce price by between 10 and $19 \%$.

The second study by Bond and Wang (2005) used the standard hedonic methodology to quantify the effect of a CPBS on sale prices of homes located near these. The study included 4283 property sales in four suburbs that occurred between 1986 and 2002 (approximately 1000 sales per suburb). The sales data that occurred before a tower was built were compared to sales data after a tower was built to determine any variance in price, after accounting for all the relevant independent variables.

Interestingly, the effect of a tower on price (a decrease of between $20.7 \%$ and $21 \%$ ) was very similar in the two suburbs where the towers were built in the year 2000, after the negative media publicity given to towers following the two legal cases outlined above. The other two suburbs that indicated a tower was either 
insignificant or increased prices by around 12\%, had towers built in them in 1994, prior to the media publicity.

The main limitation affecting this study was that there was no accurate proximity measure included in the model, such as GIS coordinates for each property. Instead, street name was included as an independent variable to help to control for the proximity effects. The current study uses GIS analysis to determine the impact that actual distance to a CPBS has on residential property prices.

\section{Property value effects from high voltage overhead transmission lines}

CPBSs are very similar structures to high voltage overhead transmission lines (HVOTLs) and their supporting structure, the pylons. Therefore, despite the limited research relating to value effects from CPBS, the body of literature on the property values effects from HVOTLs and pylons was reviewed by Bond and Wang (2005). Their review showed that proximity and views of pylons are more of a concern and affect price to a greater extent than do HVOTLs.

The price effect of the pylon does seem to be consistent between studies (i.e. negative and significant) ranging from between $12-27 \%$ depending on the distance to these. The closer the home is to a pylon, the greater the diminution in price. The effect diminishes to a negligible amount after 250 meters, on average. The impact of HVOTL-proximity on price is less certain, with this ranging from having no impact on price (the NZ study) to having a negative impact of up to $18 \%$ (the UK study).

\section{The effects of media attention on price}

Other studies confirm that media attention can have a significant impact on "stigma" and consequently prices of affected property in close proximity to environmental hazards. Slovic (1992) studied peoples' perceptions toward risks and benefits, and their preferences for various kinds of risk/benefit tradeoffs. In his discussion of stigma, Slovic associates this word with risk perception. From the results of his study he also suggests that aesthetics (ugly or upsetting), visibility, dangerous and disruptive are factors in stigmatization. He found that mechanisms of social amplification, such as heavy media coverage and attention drawn to problems by special interest groups, can increase the stigma. According to Flynn et al. (2004), the most powerful source of risk and stigma information is the news media.

A study by McCluskey and Rausser (2000) specifically addressed the existence, magnitude and duration of stigma relating to a lead smelter as changes in the relative risk occurred (before, during and after cleanup), and the causal effect on property values of media coverage over time. They found that media coverage of the environmental damage caused by the smelter had a significant negative effect on property values in close proximity to the site. 
A book review by Siemens (2003) discusses the results of the authors' (van de Griendt and Wolleswinkel) Dutch-based contaminated land case. In 1980, the first scandal of a polluted residential district in the Netherlands became news when the media zoomed in on Lekkerkerk. In their research, van de Griendt and Wolleswinkel examined movements in the value of homes in two similar toxic residential districts in Maassluis: Steendijkpolder and Noord Nieuwlandspolder Zuid. In one of the districts that received a considerable amount of negative publicity, prices collapsed dramatically and took years to recover. In the other district, where there was little media attention to the contamination issues, there was hardly any fall in prices. Even more surprising is the fact that the price dip in the second district lasted briefly. Prices quickly returned to the old level and moved in line with price fluctuations elsewhere in the South Holland province. The research revealed that negative publicity could cause a sharp fall in the value of the property.

The researchers' noted a number of factors that play an important role in the fall of housing prices in polluted districts, with the two principal factors being psychology and stigmatization. The media hype hurt housing prices in Steendijkpolder and left a smear on homes in that district. On the other hand, there was relatively little media attention of the situation in Noord Nieuwlandspolder Zuid, so the homes there escaped the pollution label.

Kinnard et al. (1995) studied sales of homes near a remediated smelter site that received increased publicity over the remediation (nature and extent) due to highly publicized legal actions to recover damages. They compared sales of houses in the affected area to those outside and also looked at proximity affects (by grouping sales into varying distance zones from the smelter) using regression analysis in a hedonic framework. The results show that declines in sales volume and prices in affected area seems to be closely linked to major publicity. They conclude that when publicity is intense and on-going value impacts persist over time. Alternatively, when publicity diminishes or ceases negative value impacts diminish or go away within a relatively short time.

Despite the varying results reported in the literature on property value effects from HVOTLs, pylons and cell phone towers, each study adds to the growing body of evidence and knowledge on this (and similar) valuation issue(s). The study reported here is one such study.

\section{Methodologies advocated to study property value effects}

The literature dealing specifically with the measurement of the impact of environmental hazards on residential sale prices (including proximity to transmission lines, landfill sites and ground water contamination) indicates the popularity of hedonic pricing models, as introduced by Court (1939) and later Griliches (1971) and further developed by Freeman (1979) and Rosen (1974). 
The more recent hedonic studies, including those by Colwell et al. (2003), Simons, Winson-Geideman, Mikelbank, (2001), and Hite et al. (2001), focus on proximity to an environmental hazard and demonstrate that this reduces residential house prices by varying amounts depending on distance from the hazard.

Thus, the method selected for the current study was a hedonic house price approach. GIS was also adopted to aid the analysis of distance to the CPBSs. The results from this study, together with the results from the previous parallel studies, will help test the hypothesis that proximity to a CPBS has a negative impact on property value and reveal the extent to which the market reacts to CPBSs.

\section{METHODOLOGY}

The method selected for this study was a hedonic house price approach. GIS was also adopted to aid the analysis of distance to the towers. The null hypothesis states that being located near a CPBS does not affect property sales prices.

\section{Data}

Sales were required both before and after the tower was built to study the effect of the existence the tower had on the surrounding property's sale prices. Residential properties that sold between 1986 and 2002, the years during which the towers were constructed and were closest to the towers were selected.

For comparison purposes, the data set included the same data as for the previous hedonic study but included a further six suburbs to give a total of ten suburbs: five suburbs with CPBSs located in them and five control suburbs without CPBSs. A total of 9,514 property sales were obtained from Headways Systems Ltd (approximately 1000 sales per suburb). The dataset was cleaned to address missing values and inconsistent coding for some variables. The observations in each suburb are listed below in Table 1. As there were no sales data available after the CPBS was built in the Upper Riccarton suburb it was not included in the analysis of the individual suburbs.

\section{Table 1: Property data}

\begin{tabular}{|l|l|l|l|l|}
\hline $\begin{array}{c}\text { Suburbs with } \\
\text { a CPBS }\end{array}$ & $\begin{array}{c}\text { Observations } \\
\text { before CPBS } \\
\text { built }\end{array}$ & $\begin{array}{c}\text { Observations } \\
\text { after CPBS } \\
\text { built }\end{array}$ & $\begin{array}{c}\text { Suburbs } \\
\text { without a } \\
\text { CPBS }\end{array}$ & Observations \\
\hline St Albans & 205 & 864 & Avonhead & 923 \\
\hline Beckenham & 963 & 209 & Bromley & 951 \\
\hline Bishopdale & 921 & 38 & Linwood & 921 \\
\hline Papanui & 1000 & 79 & Ilam & 558 \\
\hline Up. Riccarton & 913 & 0 & Spreydon & 969 \\
\hline
\end{tabular}


The other part of the data was a SAS dataset which contained 130,082 observation properties, including the land parcels where the CPBSs were located. The data for each observation property consisted of the property address and the geographical $\{x, y\}$ coordinates that relate to the property's absolute location. There were some record errors in the suburbs of Beckenham and Spreydon as indicated by coordinates for some properties being vastly different to coordinates of other properties in the same suburb. These outlier coordinates represented locations at some distance from the suburb they were supposed to relate to, so they were removed from the data.

The two datasets containing 9,514 and 130,082 observations, respectively, were combined to provide 9,514 geo-coded house sale observations. The Cartesian latitudinal and longitudinal coordinates relating to the absolute location of the CPBSs are listed in Table 2.

Table 2: Geographical coordinates of the CPBSs

\begin{tabular}{|l|l|c|c|}
\hline & \multicolumn{1}{|c|}{ Location } & X & Y \\
\hline St Albans(Telecom) & 21-25 St Albans & 2479608 & 5743830 \\
\hline Beckenham (Telecom) & 148A Colombo Street & 2480672 & 5738843 \\
\hline Bishopdale (Vodafone) & 333 Harewood Rd & 2476538 & 5746604 \\
\hline Papanui (Telecom) & 48 Langdons Road & 2478088 & 5745987 \\
\hline $\begin{array}{l}\text { Upper Riccarton } \\
\text { (Telecom) }\end{array}$ & 57 Peer Street & 2475330 & 5742286 \\
\hline
\end{tabular}

\section{Variable selection}

As each CPBS was built at a different date, the sales from each suburb were separately analysed, as well as together as a group. The uniformity of locational and neighbourhood characteristics in each of these suburbs allows the analysis to be simplified and focused on the properties' physical attributes. The relative homogeneity of housing, locational and neighbourhood attributes was verified through field inspections. The study investigates the potential impact of proximity to a tower on the price of residential property, as indicated by the dependant variable: SLNETX.

The independent variables used in the previous hedonic study were adopted for this study but the distance proxy variable, street name SISTX, and time variable, TIMESOLD. $Q$ were replaced with new, more accurate distance and time variables. Further, the $A G E$ variable used in the previous study was calculated in a different manner for the current study and renamed $N E W A G E$. The variable descriptions are listed in Table 3. 
Table 3: Variable descriptions

\begin{tabular}{|l|l|}
\hline Variable: & Definition: \\
\hline DSLNETX & CPI-deflated sales price of the house (NZ\$) \\
\hline TOWER & $\begin{array}{l}\text { An indicator variable: 0 if before the tower was built, or 1 } \\
\text { after the tower was built. }\end{array}$ \\
\hline Inv.dist & $\begin{array}{l}\text { The inverse of the square root distance to a CPBS on the non- } \\
\text { zero distances to measure the effect of distance on property } \\
\text { price. }\end{array}$ \\
\hline DIST & $\begin{array}{l}\text { Distance rings comprising four levels defined around the } \\
\text { CPBS, from level "0" which denotes there was no CPBS built } \\
\text { when the properties were sold to level "3" which denotes the } \\
\text { distance between sold properties and the CPBS is greater than } \\
600 \text { meters. }\end{array}$ \\
\hline CATGYX2 & Category of dwelling: D, E, etc \\
\hline CATGYX4 & Quality of the structure: A, B, C \\
\hline SLDATX & Actual date when the property sold. \\
\hline NEWAGE & The year the house was built. \\
\hline LANDAX & Land area (ha). \\
\hline MATFAX & Total floor area (m ${ }^{2}$ ). \\
\hline WALLCNX & Wall construction: W, B, C, etc. \\
\hline ROOFCNX & Roof construction: W, B, C, etc. \\
\hline
\end{tabular}

${ }^{1}$ Sales price is the dependent variable.

\section{Time adjusting property sales price}

Due to the effect of time on property sales prices, time must be allowed for in the model to permit a price comparison from one period to another. One way to account for this is to deflate the sales price by the corresponding consumer price index (CPI). Preferably this would be the house component of the CPI in the relevant study area. In this research, the sales data came from Christchurch city so the Christchurch house component of CPI should be used to deflate the sales prices of the properties. However, since only a national house CPI is available from Statistics New Zealand, this was used to deflate the sales prices in the data set. As a precaution, time was included as an explanatory variable (SLDATX) in all the regression models. This variable represents the actual sales date. As SLDATX was generally significant, it would appear that using the CPI-deflated house price, DSLNETX, does not completely diminish the time effect on the sales price.

\section{Distance to the CPBS}

The hypothesis and main focus for this study is that we expect that property price will be lower the closer the property is to a CPBS. To measure the effect of distance on property price two methods were used. One method was to treat the distance numerically in the model. Where a property was sold before the CPBS 
was built the distance is recorded as zero. The non-zero distance measurements indicate the distance between the CPBS and properties.

The distribution plot of distance against property price indicated that there was not a strong relationship between the two variables so the distance variable was transformed to better capture the relationship between the distance and property price. The inverse of the square root distance on the non-zero distances provided a much better distribution pattern. The new variable, called inv.dist, shows that as the distance increases, inv.dist decreases; if the distance decreases, inv.dist increases.

The second method used to measure the effect of distance involved making a new categorical variable. First, the distance was determined from the $\mathrm{X}$ and $\mathrm{Y}$ coordinates of each property and the CPBSs. The categorical variable, DIST, was then established containing four levels. The four levels comprised circular rings that were defined around the CPBS based on distances to it. The first level " 0 " denotes there was no CPBS built when the properties were sold. The second level " 1 " denotes that the distance between sold properties and the CPBS is between 0 to 300 meters, the third level " 2 " denotes that the distance between sold properties and the CPBS is between 301 to 600 meters, and the fourth level " 3 " denotes the distance between sold properties and the CPBS is greater than 600 meters.

These distance rings are within the range of distances used in other similar proximity studies of the effects of high voltage overhead transmission lines, hazardous waste and railway tracks on property values (see for example: Hamilton and Schwann (1995), they used $100 \mathrm{~m}$ and $200 \mathrm{~m}$ distances as did Strand and Vagnes (2001); Reichert (1997) used four 2250ft (658m) concentric zones; Colwell $(1990)$ used $50 \mathrm{ft}(15 \mathrm{~m}), 200 \mathrm{ft}(60 \mathrm{~m})$ and greater than $200 \mathrm{ft}(60 \mathrm{~m})$ distances; Bond and Hopkins (2000) and Des Rosiers (2002) both used 50m (165ft) concentric zones).

\section{House age}

For the age of homes, a different variable was adopted to that used in the previous hedonic study. The new variable called $N E W A G E$ was calculated by subtracting the sales date of the property from the time the property was built. This was used to calculate the actual age of the property at the date the property was sold rather than when the market study was conducted as in the previous study. It is expected that house age will have a negative effect on property price (except for homes of an historic nature that commonly have a positive impact on price).

\section{Property categories}

The variable CATGYX comprises four characters indicating the type, age and quality of residential property. The first character indicates the zoning of the property. As this was the same for every property (i.e. " $R$ " indicating residential), it was not included in the analysis. Also, the third character that records the decade 
during which the structure was built was excluded from the analysis as building age is taken into account in the $N E W A G E$ variable. The second character describes the type of residence (for example, single family home, home ownership units, etc). The last character records the quality of the structure.

\section{Wall and roof materials}

The variables WALLCNX and ROOFCNX indicate the types of wall and roofing materials of the home. While both variables supposedly have 13 levels representing the different materials most of the roofing materials are recorded as iron, tile or concrete. Thus, for the analysis of ROOFCNX only these three materials were used but with an additional material denoted by "O" which included all other types of roofing material.

Before presenting the final multiple regression results, the section following outlines the results of an initial exploratory data analysis.

\section{EXPLORATORY DATA ANALYSIS}

In order to better understand the data, an exploratory analysis was undertaken to compare sales prices between the suburbs with a CPBS and those suburbs without a CPBS and to compare sale prices over time.

\section{Housing characteristics}

\section{Property prices between suburbs}

Figure 1 shows there is considerable difference in property prices between the different suburbs. Property prices in St Albans, Ilam, Avonhead and Upper Riccarton are much higher than prices in the other suburbs. This confirms the demographic statistics obtained for each suburb (as presented in Bond and Beamish, 2005). Residents from these four suburbs had the highest levels of household and family incomes as well as the highest levels of education. Due to these differences, a separate analysis was undertaken for each suburb together with a combined analysis for all suburbs. 
Figure 1: Property Prices between Suburbs

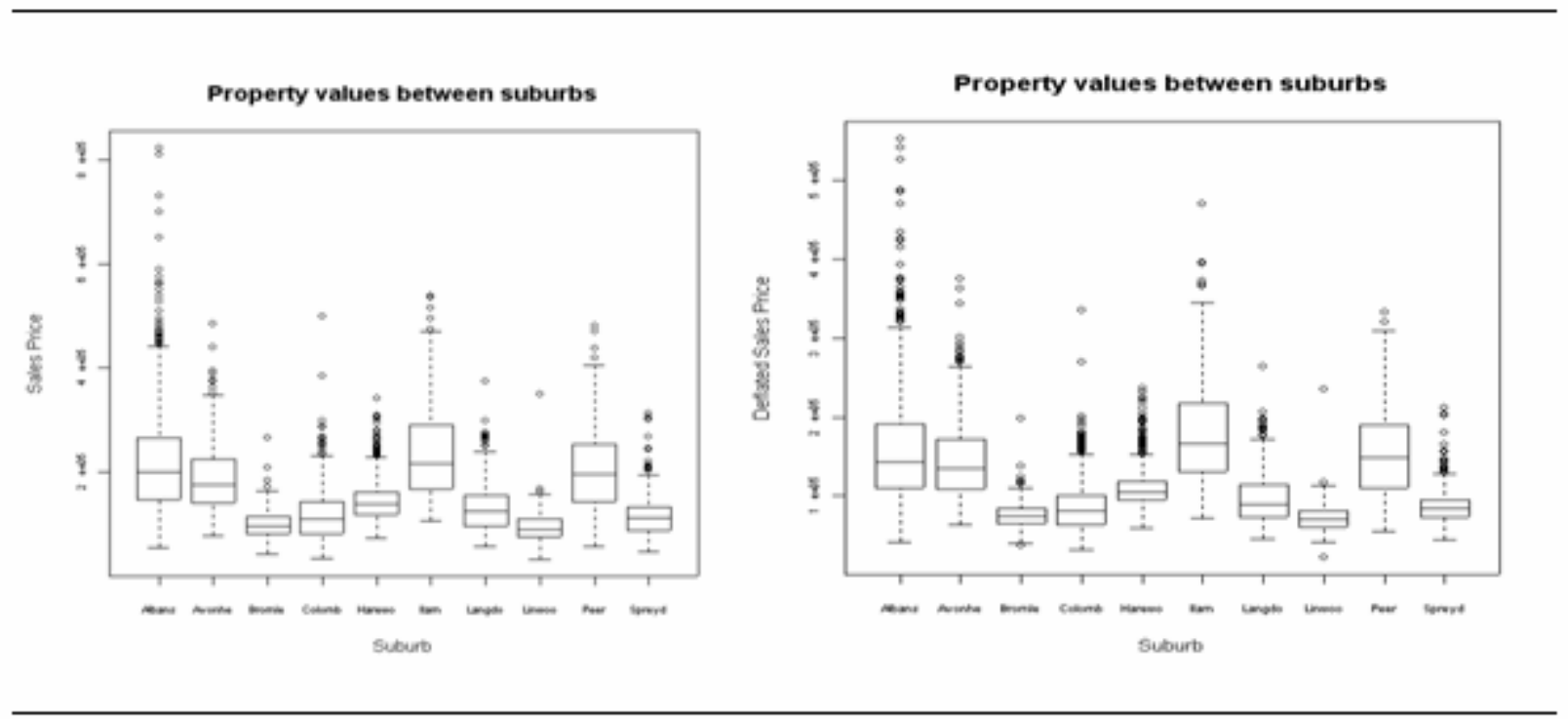


Figure 2: Property Price versus Time

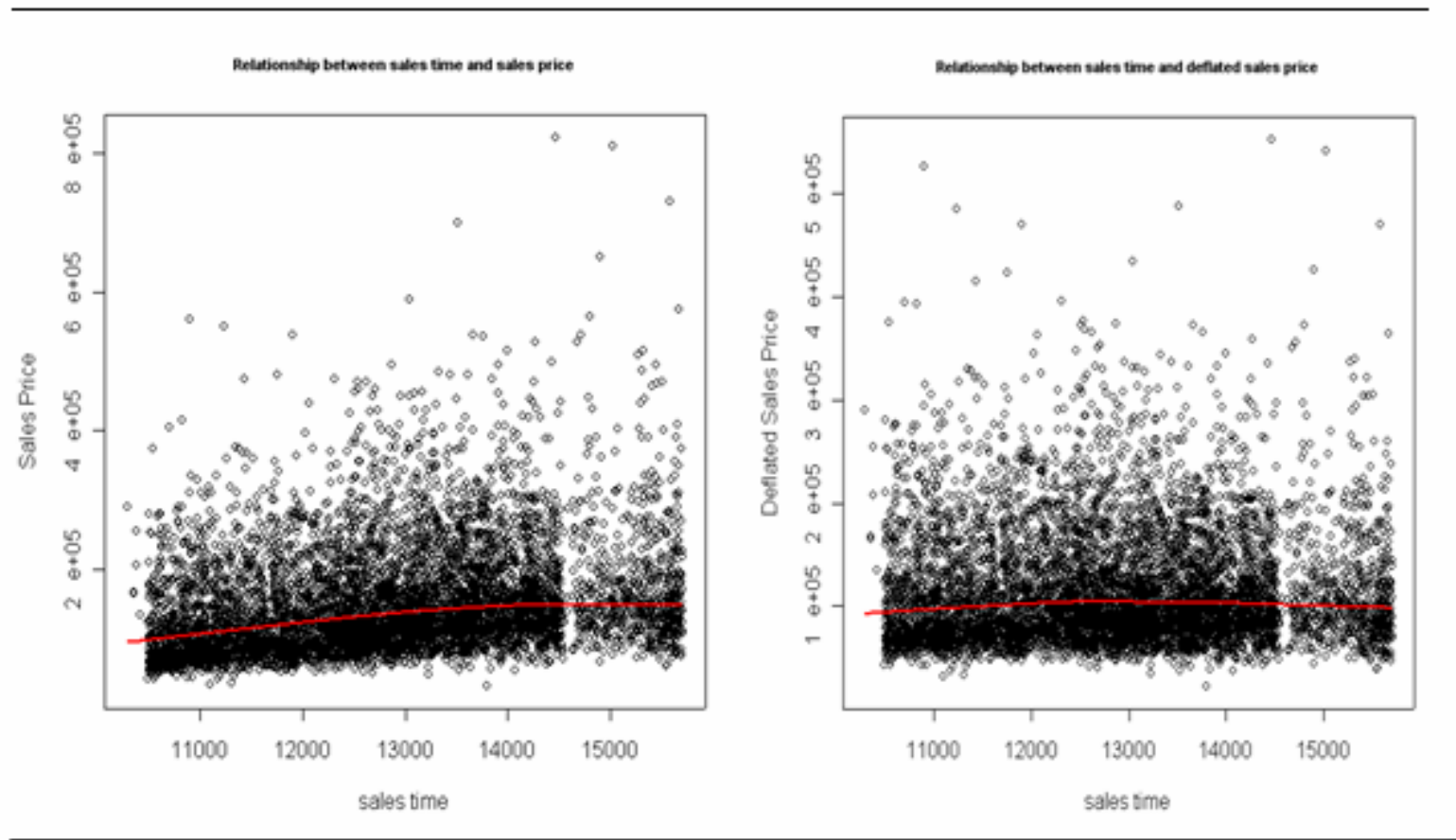




\section{Property price versus time}

Figure 2 shows that property prices, both before and after CPI-adjustment, generally increase and then level out in the last period. However, after deflating the sales prices the increase is much less. Regardless, this indicates that time has a significant effect on property price, as would be expected.

The next section outlines the results from the multiple regression analyses. A comparison of these results to the results from the earlier study is covered in Section 5 .

\section{EMPIRICAL RESULTS}

This section presents the results from the various multiple regression models used to quantify the relationship between the response variable, property sales price, and the explanatory variables.

The model of choice is one that best represents the relationships between the variables and has a small variance and unbiased parameters. Various models were tested and the results are described in the next section. The following statistics were used to help select the most appropriate model: the adjusted coefficient of determination (adjusted $\mathrm{R}^{2}$ ); the standard error of the regression equation; the Akaike Information Criterion (AIC) and Bayesian Information Criterion (BIC) statistics; t-test of significance of the coefficients and F-statistic.

\section{Significance of the variables and the equation with "TOWER" included}

As hedonic price estimates can vary significantly across different functional forms, various commonly used functional forms were examined to determine the model specification that best describes the relationship between price and the independent variables. It was found that the best result was obtained from using the log of DSLNETX, the log of both LANDAX and MATFAX, and the linear form of all the dummy variables.

In the semi-logarithmic equation, the interpretation of the dummy variable coefficients involves the use of the formula: $100\left(\mathrm{e}^{\mathrm{bn}}-1\right)$, where bn is the dummy variable coefficient (Halvorsen \& Palmquist, 1980).

A multiple regression model was fitted to the data that included the variable "TOWER". This was done using the statistical software " $R$ " to check whether or not the presence of a CPBS has an affect on property sales prices. The resulting model included all the available variables as follows: 


\section{Tower}

The regression output in Appendix I shows that most of the coefficients are significant except the majority of wall materials $(W A L L C N X)$ and purpose-built rental flats $(C A T G Y X 2)$. Only the wall material of iron (WALLCNXI) was significant in the model. The coefficient of determination $\left(\mathrm{R}^{2}\right)$ indicates that approximately $83.5 \%$ of the variation in sale price is explained by the variation in the independent variable set. Further, the p-value of the F-statistic is approximately 0 indicating the good fit of the data.

The TOWER coefficient is -0.0229 , and the p-value is 0.0088 , which indicates a negative relationship between the presence of a CPBS and price. Quantitatively, the presence of a CPBS decreases price by $2.3 \%$, $\left(1-\mathrm{e}^{-0.0229}\right)$, when other explanatory variables are held constant. Although this percentage is small, a CPBS does have a significant negative influence on price.

The most significant variables were $\log (M A T F A X)(\log$ of total floor area) and $N E W A G E$. The positive $\log$ of total floor area shows that prices increase with increasing size while the negative age coefficient shows that prices decrease the greater the age of a home is. The regression coefficient on $\log M A T F A X$ is 0.632 , which indicates that, on average, a $10 \%$ increase in floor area $\left(\mathrm{m}^{2}\right)$ will generate a $6.32 \%$ increase in price. The negative coefficient for $N E W A G E$ indicates that, when all the other variables are held constant, for each additional year of age the price would decrease by $\mathrm{e}^{0.00422} \approx 1.00422(0.42 \%)$.

Another strongly significant variable was SLDATX. Though very small, the positive coefficient indicates an appreciation of sale price over time even after the CPI adjustment.

\section{General model including the variable "Distance"}

A multiple regression model was fitted to the data that included the variable inv.dist to determine whether or not distance to a CPBS has an affect on price. The model is as follows:

$$
\begin{aligned}
\log (\text { DSLNETX })= & \boldsymbol{\alpha}+\boldsymbol{\beta}_{\mathbf{1}} \text { CATGYX2 }+\boldsymbol{\beta}_{\mathbf{2}} \text { CATGYX4 }+\boldsymbol{\beta}_{\mathbf{3}} \text { NEWAGE } \\
& +\boldsymbol{\beta}_{\mathbf{4}} \log (\text { LANDAX })+\boldsymbol{\beta}_{\mathbf{5}} \log (\text { MATFAX })+\boldsymbol{\beta}_{\mathbf{6}} \text { SLDATX1 } \\
& +\boldsymbol{\beta}_{7} \text { WALLCNX }+\boldsymbol{\beta}_{\mathbf{8}} \text { ROOFCNX }+\boldsymbol{\beta}_{\mathbf{9}} \text { SUBURB }+\boldsymbol{\beta}_{\mathbf{1 0}} \text { inv.dist }
\end{aligned}
$$

This model also fitted the data very well, explaining $83.2 \%$ of the variability in sales price. All explanatory variables have significant coefficients except for wall materials (WALLCNX) (see Appendix II for the regression output). 
The variable inv.dist, which measures the effect of distance on price, has a negative coefficient of -0.368 , with a significant $\mathrm{p}$-value of 0.0082 , indicating there is strong evidence that distance has a significant effect on the logged sales price. Thus, logged sales price decreases as the inverse of the squared root distance between a CPBS and a property increases. In other words, price decreases as the distance between a CPBS and a property decreases, when all other explanatory variables are held constant. For example, when the distance between a CPBS and a property is 50 meters, the price of the property will drop by $5.07 \%\left(1-e^{-0.368 \times \frac{1}{\sqrt{50}}}\right)$. Distance has a larger negative effect on price than does the mere presence of a CPBS, as indicated in the previous model. Table 4 gives the magnitude of the decrease in property prices for the different distances between the CPBS and the properties.

Table 4: Decreases in property prices with increasing distance

\begin{tabular}{|c|c|c|}
\hline Distance (meters) & Decrease in price (\%) & Increase in distance \\
\hline 10 & 10.99 & - \\
\hline 50 & 5.07 & 40 \\
\hline 100 & 3.61 & 50 \\
\hline 200 & 2.57 & 100 \\
\hline 500 & 1.63 & 300 \\
\hline
\end{tabular}

From Table 4, it appears that the effect on property price is negligible after 300 meters from a CPBS. This is similar to the findings of other proximity studies (see for example, Hamilton and Schwann (1995) and Strand and Vagnes (2001)).

As in the previous model, the most significant variables were $\log (M A T F A X)(\log$ of total floor area) and $N E W A G E$. Further, the variable coefficients are very similar to the previous model. The regression coefficient on $\log M A T F A X$ is 0.624 , which indicates that, on average, a $10 \%$ increase in floor area $\left(\mathrm{m}^{2}\right)$ will generate a $6.24 \%$ increase in price. The negative coefficient for $N E W A G E$ indicates that, when all the other variables are held constant, for each additional year of age, the price would decrease by $\mathrm{e}^{0.00419} \approx 1.0042(0.42 \%)$.

A multiple regression model was fitted that includes the variable DIST, a categorical distance variable, taking values $0,1,2,3$. Each number represents a predetermined circular distance ring around the CPBS. The model is the same as previously used but includes DIST instead of inv.dist or TOWER. The output of this model is shown in Appendix III. 
Similar to the results from the model that included the variable "TOWER", the output for this model shows that most of the coefficients are significant except wall materials $(W A L L C N X)$ and purpose-built rental flats $(C A T G Y X 2 R)$. The coefficient of determination $\left(\mathrm{R}^{2}\right)$ indicates that approximately $83.5 \%$ of the variation in sale price is explained by the variation in the independent variable set.

The first two categories of the distance variable are strongly significant in the model. However, category 3 which represents a distance greater than 600 meters from a property to a CPBS is insignificant in the model. Prices of properties located between 0 and 300 meters from a CPBS decrease by $2.74 \%\left(1-\mathrm{e}^{-0.0278}\right)$ while those located between 300 and 600 meters from a CPBS will decrease by $2.87 \%\left(1-\mathrm{e}^{-0.0291}\right)$ relative to properties that sold prior to the CPBS being built when holding other explanatory variables constant. Thus, a CPBS has a significant, albeit minimal, effect on prices of property located within 600 meters of a CPBS.

As with the previous two models the most significant variables were log (MATFAX) (log of total floor area) and NEWAGE. The regression coefficients of each variable are also very similar to those obtained in the previous models.

\section{CASE MODEL - ST. ALBANS}

The discussion above relates to the results from analysis of the whole dataset. These indicate that CPBSs have a significant, but minimal, effect on the prices of proximate properties. However, differences might exist in the effect that CPBSs have on property prices between suburbs, since the distribution of the property sales prices is quite different in each. Accordingly, this section focuses on investigating whether or not the presence of a CPBS has an impact on property prices within each of the suburbs.

In St Albans, 1069 properties sold and a large number of these (864) sold after the CPBS was built. Three separate multiple regression models were fitted to the data, one with each variable TOWER, inv.dist and DIST included, respectively. As the regression coefficients of each variable are very similar to those obtained in the previous models only the coefficients of the variables of interest, TOWER, inv.dist and DIST, are shown below in Table 5.

Table 5: Coefficients of TOWER, inv.dist and DIST for St. Albans

\begin{tabular}{|l|l|l|l|l|l|}
\hline Variable: & TOWER & Inv.dist & DIST1 & DIST 2 & DIST 3 \\
\hline Coefficients & $1.48 \mathrm{e}-01$ & $8.99 \mathrm{e}-01$ & $1.45 \mathrm{e}-01$ & $1.53 \mathrm{e}-01$ & $1.44 \mathrm{e}-01$ \\
\hline P-value & $0.0000^{* * *}$ & $0.0000^{* * *}$ & $0.0000^{* * *}$ & $0.0000^{* * *}$ & $0.0000^{* * *}$ \\
\hline
\end{tabular}


The variables TOWER, inv.dist and DIST are significant in the respective models. However, surprisingly, the coefficients of each variable are positive indicating that a CPBS in St Albans has a positive effect on the property prices. All things being equal, with the variable TOWER included in the model, the presence of the CPBS will increase property values by $16 \%\left(\mathrm{e}^{0.148}\right)$.

This was a similar result to that obtained in the earlier study that did not include a distance variable. In that study sales prices increased by $12 \%$. An explanation given for this was that the TOWER was built in 1994 before the negative media attention to the adverse health affects from CPBSs. Alternatively, there is a collinearity problem in the current St Albans model. The variable SLDATX1 which measures the time effect on the property prices was not significant in the model, and possibly the variable TOWER may include some of these time effects.

When the variable inv.dist is included in the model, the results indicate that as the inv.dist increases, the logged property price in St Albans also increases when holding other explanatory variables constant. That is to say, as the distance between the CPBS and the property decreases, then the property values increase when holding the other variables constant. For example, at 50 meters distance, the property prices increase by $13.56 \%\left(e^{0.899 \times \frac{1}{\sqrt{50}}}-1\right)$ and by $9.41 \%$ at 100 meters.

When the variable DIST is included in the model, all levels of the variable have significant and positive coefficients. Prices will increase by $15.6 \%\left(\mathrm{e}^{0.145}\right)$ when the property is located in the range of zero to 300 meters from the CPBS, and by $16.5 \%\left(\mathrm{e}^{0.153}\right)$ and $15.5 \%\left(\mathrm{e}^{0.144}\right)$ when the property is located between 300 and 600 meters and more than 600 meters from a CPBS, respectively. Since DIST1, DIST2, DIST3 have similar coefficients, this is very like the model that included the variable TOWER.

St Albans is an up-market Christchurch suburb, with higher property prices due to being located near public transportation, good educational facilities, parks, etc and it has better socio-economic characteristics than other suburbs. Thus, the variable "distance" might include some of these influences, in addition to the effect of distance to a CPBS. Alternatively, it is possible that as it is a more affluent suburb more homeowners may own and use cell-phones than homeowners in other suburbs, and hence they may prefer the better cell phone coverage that they would get by being near a CPBS.

\section{CASE MODEL - BECKENHAM}

The same functional form used in the previous models was applied to Beckenham to test the effect that the various variables TOWER, inv.dist and DIST have on sales price. In Beckenham, 1172 properties sold and 209 of these sold after the CPBS 
was built, Three separate multiple regression models were fitted to the data, one with each variable TOWER, inv.dist and DIST included, respectively. As the regression coefficients of each variable are very similar to those obtained in the previous models only the coefficients of the variables of interest, TOWER, inv.dist and DIST, are shown in Table 6, below.

Table 6: Coefficients of TOWER, inv.dist and DIST for Beckenham

\begin{tabular}{|l|l|l|l|l|l|}
\hline Variable: & TOWER & Inv.dist & DIST1 & DIST 2 & DIST 3 \\
\hline Coefficients & $-1.81 \mathrm{e}-01$ & $-2.85 \mathrm{e}+00$ & $-1.74 \mathrm{e}-01$ & $-1.74 \mathrm{e}-01$ & $-2.03 \mathrm{e}-01$ \\
\hline P-value & $0.0000^{* * *}$ & $0.0000^{* * *}$ & $0.0000^{* * *}$ & $0.0000^{* * *}$ & $0.0000^{* * *}$ \\
\hline
\end{tabular}

In Beckenham, TOWER, inv.dist and DIST are significant in the respective models. All of them have a negative relationship with the logged sales price. With the variable TOWER included in the model, the presence of the CPBS will decrease property price by $16.56 \%\left(1-\mathrm{e}^{-0.181}\right)$ when holding other explanatory variables constant.

When the variable inv.dist is included in the model, the results indicate that as the inv.dist increases one unit, the logged property price will decrease 2.85 units. For example, in Beckenham, the minimum distance of a home to a CPBS is about 97 meters, the property prices corresponding to this distance will decrease by $25.13 \%$ $\left(1-e^{-2.85 \times \frac{1}{\sqrt{97}}}\right)$ when holding other variables constant. This is a surprisingly large
decrease in price.

The output of the model with variable DIST included shows that where the distance of the property from the CPBS is between 0 and 300 meters or 300 and 600 meters, the price will decrease by $15.9 \%\left(1-\mathrm{e}^{-0.174}\right)$ relative to properties that sold before the CPBS was built. If the distance is greater than 600 meters, the price will decrease by $18.37 \%\left(1-\mathrm{e}^{-0.203}\right)$ relative to properties that sold before the CPBS was built. Thus, there is a greater negative impact on price when the distance between the property and the CPBS is greater. This result appears to be inconsistent with expectation and the results from the previous models. It is possible that the variable inv.dist not only measures the effect of CPBSs on sales price, but also reflects the effect of other influences not included in the model.

\section{CASE MODEL - BISHOPDALE}

In Bishopdale, 959 properties sold and only 38 of these sold after the CPBS was built. Despite this data discrepancy before and after the CPBS was built, three 
separate multiple regression models were fitted to the data, one with each variable TOWER, inv.dist and DIST included, respectively. The results from the separate models indicate that in Bishopdale the TOWER and two separate distance variables are significant in the models and all have a negative relationship with the logged sales price. The coefficients of the variables of interest, TOWER, inv.dist and DIST, are shown below in Table 7.

Table 7: Coefficients of TOWER, inv.dist and DIST for Bishopdale

\begin{tabular}{|l|l|l|l|l|}
\hline & TOWER & Inv.dist & DIST1 & DIST 2 \\
\hline Coefficients & $-9.86 \mathrm{e}-02$ & $-1.62 \mathrm{e}+00$ & $-1.34 \mathrm{e}-01$ & $-9.18 \mathrm{e}-02$ \\
\hline P-value & $0.0000 * * *$ & $0.0000 * * *$ & $0.0000 * * *$ & $0.0000 * * *$ \\
\hline
\end{tabular}

The presence of the CPBS will decrease the sales price by $9.39 \%\left(1-\mathrm{e}^{-0.0986}\right)$ when holding other factors constant. As inv.dist is increased by one unit, the logged property price will decrease by 1.62 units when holding other variables constant. For example, property prices at 50 meters distance from the CPBS will decrease by $20.48 \%\left(1-e^{-1.62 \times \frac{1}{\sqrt{50}}}\right)$ and by $15 \%$ at 100 meters.

The coefficients from the model incorporating the categorical distance variable look reasonable. However, no properties sold that were located further than 600 meters from the CPBS so there were only two levels for the categorical distance variable. When holding other explanatory variables constant property prices will decrease by $12.54 \%\left(1-\mathrm{e}^{-0.134}\right)$ when a property is located between 0 and 300 meters of a CPBS. Prices will decrease by $8.96 \%\left(1-\mathrm{e}^{-0.0939}\right)$ when a home is located between 300 and 600 meters of a CPBS.

\section{CASE MODEL - PAPANUI}

In Papanui, 1079 properties sold and 79 of these sold after the CPBS was built. The results from the three separate models indicate that all variables are significant. The coefficients are listed in Table 8.

Table 8: Coefficients of TOWER, inv.dist and DIST for Papanui

\begin{tabular}{|l|l|l|l|l|l|}
\hline & TOWER & Inv.dist & DIST1 & DIST 2 & DIST 3 \\
\hline Coefficients & $-8.17 \mathrm{e}-02$ & $-2.24 \mathrm{e}+00$ & $-7.02 \mathrm{e}-03$ & $-1.55 \mathrm{e}-01$ & $-6.70 \mathrm{e}-02$ \\
\hline P-value & $0.00142 * *$ & $0.0000 * * *$ & 0.93766 & $0.00147 * *$ & $0.01888 *$ \\
\hline
\end{tabular}


In Papanui, when TOWER is included in the model, the presence of the CPBS will decrease sales prices by $7.85 \%\left(1-\mathrm{e}^{-0.0817}\right)$ when holding other variables constant. Property sales prices will decrease as the variable inv.dist increases, or, in other words, sales prices will decrease as the distance between the CPBS and the property decreases. For example, in Papanui, the minimum distance between the CPBS and the property is about 177 meters, so prices will decrease by a factor of $15.50 \%\left(1-e^{-2.24 \times \frac{1}{\sqrt{177}}}\right)$.

However, in the model that includes the categorical distance properties located between 0 and 300 meters do not sell for significantly different prices when compared to the properties that sold before the CPBS was built, which is at odds to the previous result from the model including inv.dist. The reason for this is due to there being only 3 property sales located within 0 to 300 meters of a CPBS, so there are insufficient observations in this category for a valid statistical comparison. In the other two distance categories, the property sales prices decrease by $14.36 \%\left(1-\mathrm{e}^{-0.1 .55}\right)$ and $6.48 \%\left(1-\mathrm{e}^{-0.067}\right)$, respectively. These sizes of the decrease in the property values due to the effect by the CPBS seem reasonable.

\section{DISCUSSION AND COMPARISON WITH THE PREVIOUS STUDY}

The analysis showed that the most significant variables and their effect on price were similar between the four suburbs: St. Albans, Beckenham, Papanui, and Bishopdale. This indicates the relative stability of the coefficients between each model. The overall results indicate that the presence of a CPBS has a significant and negative effect on property prices. This effect is not very strong when the variable TOWER is included in the model fitted to the entire dataset. However, the effect in each suburb is quite pronounced. Table 9 summarizes the results and includes the results from the previous study (shown in brackets and italics) for comparison. 
Table 9: Coefficients of TOWER, inv.dist and DIST

\begin{tabular}{|c|c|c|c|c|c|c|}
\hline Model: & & $\begin{array}{l}\text { TOWER } \\
\text { (Previous) }\end{array}$ & Inv.dist & DIST1 & DIST 2 & DIST 3 \\
\hline \multirow[t]{2}{*}{ All Suburbs } & Coefficients & $-2.29 \mathrm{e}-02$ & $-3.68 \mathrm{e}-01$ & $-2.78 \mathrm{e}-02$ & $-2.91 \mathrm{e}-02$ & $-3.98 \mathrm{e}-03$ \\
\hline & Value Effects & $-2.3 \%$ & $\begin{array}{l}50 \mathrm{~m} @-5.07 \% \\
100 \mathrm{~m} @-3.61 \% \\
\end{array}$ & $-2.7 \%$ & $-2.87 \%$ & Insignif. \\
\hline \multirow[t]{2}{*}{ 1. St Albans 1994} & Coefficients & $1.48 \mathrm{e}-01$ & $8.99 \mathrm{e}-01$ & $1.45 \mathrm{e}-01$ & $1.53 \mathrm{e}-01$ & $1.44 \mathrm{e}-01$ \\
\hline & Value Effects & $+16 \%(+12 \%)$ & $\begin{array}{l}50 \mathrm{~m} @+13.6 \% \\
100 \mathrm{~m} @+9.4 \%\end{array}$ & $+15.6 \%$ & $+16.5 \%$ & $+15.5 \%$ \\
\hline \multirow[t]{2}{*}{ 4.Beckenham 2000} & Coefficients & $-1.81 \mathrm{e}-01$ & $-2.85 e+00$ & $-1.74 \mathrm{e}-01$ & $-1.74 \mathrm{e}-01$ & $-2.03 e-01$ \\
\hline & Value Effects & $\begin{array}{l}-16.56 \% \\
(-20.7 \%) \\
\end{array}$ & 97m@-25.13\% & $-15.9 \%$ & $-15.9 \%$ & $-18.37 \%$ \\
\hline \multirow[t]{2}{*}{ 3.Bishopdale 1994} & Coefficients & $-9.86 \mathrm{e}-02$ & $-1.62 \mathrm{e}+00$ & $-1.34 \mathrm{e}-01$ & $-9.18 \mathrm{e}-02$ & \\
\hline & Value Effects & $\begin{array}{l}-9.39 \% \\
\text { (insignif.) }\end{array}$ & $\begin{array}{l}50 \mathrm{~m} @-20.4 \% \\
100 \mathrm{~m} @-15 \% \\
\end{array}$ & $-12.54 \%$ & $-8.96 \%$ & \\
\hline \multirow[t]{2}{*}{ 2. Papanui 2000} & Coefficients & $-8.17 \mathrm{e}-02$ & $-2.24 \mathrm{e}+00$ & $-7.02 \mathrm{e}-03$ & $-1.55 \mathrm{e}-01$ & $-6.70 \mathrm{e}-02$ \\
\hline & Value Effects & $\begin{array}{l}-7.85 \% \\
(-21 \%)\end{array}$ & 177m@-15.5\% & Insignif. & $-14.36 \%$ & $-6.48 \%$ \\
\hline
\end{tabular}

In terms of the effect that proximity to a CPBS has on price, the overall results indicate that this is significant and negative. Generally, the closer to the CPBS a property is the greater the decrease in price. However, there are differences in the results between suburbs. St Albans actually shows the reverse effect with prices increasing closer to the CPBS. Some explanations for this are offered next.

In the previous study, it was suggested that the difference in results between suburbs was due to the date that the towers were constructed. The effect of TOWER on price was similar in the two suburbs where the towers were built in the year 2000 (Papanui and Beckenham). It was suggested that this may be due to the much greater media publicity given to CPBSs after the two legal cases in Christchurch in 1996 and 1999 respectively. The other two suburbs that indicated a tower was either insignificant (Bishopdale) or increased prices by around 12\% ( $\mathrm{St}$ Albans), had towers built in them in 1994, prior to the media attention.

However, in the current study, the results for Bishopdale were similar to the other two suburbs that showed a negative effect on price even though the CPBS in Bishopdale was built in 1994 prior to the adverse publicity. This result brings into question the validity of the above hypothesis. Yet the explanation may still hold when considering the number of sales before and after the CPBS was built in each suburb. For example, in Bishopdale only 38 properties $(3.8 \%$ of total sales for the suburb) sold after the CPBS was built compared to $6.8 \%$ in Papanui, $15.15 \%$ in Beckenham and $44.68 \%$ in St Albans. This low number of sales may mean that the results are not fully representative of all properties that sold in Bishopdale after the CPBS was built.

Another explanation for the difference in results between suburbs relates to the differences in the social structure of each neighbourhood. St Albans has the highest 
socio-economic characteristics, followed by Papanui and Bishopdale. Beckenham has the lowest socio-economic characteristics. This pattern follows the order of value effect on sales price of the presence of a CPBS. The better suburbs are less affected $(+16 \%$ in St Albans and $-7.85 \%$ in Papanui) compared to the lower socioeconomic areas which have the greatest negative impact on prices from proximity to a CPBS (-9.39\% in Bishopdale and $-20.7 \%$ in Beckenham). As suggested earlier, the better suburbs may want to be closer to the CPBS for the better cell phone coverage this affords (assuming a higher percentage of the more affluent population will use a cell phone) and so do not perceive these so negatively, particularly prior to the media attention to CPBSs. Conversely, the CPBSs in the more affluent suburbs may be better concealed from view.

The expectation was that the negative effect on price of proximity to a CPBS would be greater the closer a property was to a CPBS, reducing with distance from it. While this was the case for two suburbs (Bishopdale and Papanui) the results were mixed and may be explained by the differences in how visible the CPBS is from each property. This will be affected by topographical differences, objects such as trees and buildings that may conceal it and the height and design of the CPBS itself. Thus, the distance variables are an imperfect measure of the effect of living near a CPBS.

\section{LIMITATIONS AND AREAS FOR FURTHER STUDY}

The main limitation affecting this survey was in finding case study areas where CPBSs were highly visible from the majority of homes. This deficit was very difficult to control for. Thus, caution must be used in making generalizations from the study or applying the results directly to other similar studies or valuation assignments. Factors that could affect results are the style and appearance of the CPBS, how visible it is to residents, and the socio-economic make-up of the resident population.

It must be kept in mind that these results are the product of only one case study carried out in a specific area (Christchurch) at a specific time (2003/2004). The above results indicate that value-effects from CPBSs can vary over time as market participant's perceptions change due to increased public awareness regarding the potential averse health and other effects of living near a CPBS. To confirm this, many similar studies, of similar design to allow comparison between them, need to be conducted over time and the results made public.

With the sharing of results from similar studies, a global database could be developed to assist valuers in determining the perceived level of risk associated with CPBSs and other similar structures from geographically and socioeconomically diverse areas. This would aid in the valuation of property affected by these structures, anywhere in the world. 


\section{SUMMARY AND CONCLUSION}

This research was a refinement of a previous study that looked at the effect that the presence of a CPBS has on residential property prices (see Bond and Wang, 1995). The current study looked more specifically at distance impacts by investigating how proximity to a CPBS affects the price of such properties. It did this by focusing on four case study neighbourhoods in Christchurch, NZ, and analyzing property sales prices both before and after a CPBS was built in each suburb using multiple regression analysis within a hedonic pricing framework.

The results indicate that property prices decrease by around $15 \%$ after a CPBS is built. This effect generally reduces with distance from the CPBS and is almost negligible after about 300 meters. However, this result varied between neighbourhoods, with a positive impact on price being recorded in one neighbourhood, possibly due to the CPBS being built before there was any negative media publicity towards CPBSs and that the CPBS is better concealed than in the other neighbourhoods.

\section{REFERENCES}

AGNIR (2003). Health effects from radiofrequency electromagnetic fields. Report of an Advisory Group on Non-ionising Radiation. Doc NRPB, 14(2), 1-177.

Bond, S.G. and Wang, K. (2005). "The Impact of Cell Phone Towers on House Prices in Residential Neighbourhoods", The Appraisal Journal, Volume LXXIII, No.3, pp.256-277.

Bond, S.G., Beamish, K. (2005). "Cellular Phone Towers: Perceived Impact on Residents and Property Values", Pacific Rim Property Research Journal, Vol. 11, no. 2, pp. 158-177.

Bond, S.G. \& Hopkins, J. (2000)."The Impact of Transmission Lines on Residential Property Values: Results of a Case Study in a Suburb of Wellington, New Zealand", Pacific Rim Property Research Journal, Vol.6, No. 2, pp.52-60.

Chen, G., Upham, B.L., Wei Sun, Chang, C., Rothwell, E.J., Chen, K., Yamasaki, H., and Trosko, J.E. (2000), "Effect of Electromagnetic Field Exposure on Chemically Induced Differentiation of Friend Erythroleukemia Cells", Environ Health Perspect. Vol.108:967-972.

Cherry, N. (2000), "Health Effects Associated with Mobil Base Stations in Communities: The Need for Health Studies," Environmental Management and Design Division, Lincoln University, June 8. Available from: http://pages.britishlibrary.net/orange/cherryonbasestations.htm. 
Christchurch City Council website. Available from: www.ccc.govt.nz/index.asp

Colwell, P. (1990), "Power Lines and Land Value", Journal of Real Estate Research, Vol. 5, No. 1, Spring.

Colwell, P., Bradford, C., Watkins, C. and Leishman, C. (2003), "Estimating the Impact of Environmental Contamination on Condo prices: A hybrid repeatsale/hedonic approach", June, European Real Estate Society Conference, Helsinki, Finland.

Court, A.T. (1939). Hedonic Price Indexes with Automotive Examples, in: The Dynamics of Automobile Demand. General Motors, New York.

Des Rosiers, F. (2002), "Power Lines, Visual Encumbrance and House Values: A Microspatial Approach to Impact Measurement", Journal of Real Estate Research, Vol.23, No.3, pp. $275-301$.

Flynn, J., MacGregor, D.G., Hunsperger, W., Mertz, C.K., Johnson, S.M. (2004), "Survey Approach for Demonstrating Stigma Effects in Property Value Litigation", The Appraisal Journal, 72 (1): 35-45.

Freeman, A. M. I. (1979), The Benefits of Environmental Improvement, John Hopkins Press, Baltimore, MD.

Griliches, Z. (ed.) (1971). Price Indexes and Quality Change. Harvard University Press, Cambridge, Mass.

Hamilton, S. and Schwann, G. (1995), "Do High Voltage Electric Transmission Lines Affect Property Value?” Land Economics, Vol.71, No. 4, pp. 436-444.

Halvorsen, R. and Palmquist, R. (1980), "The Interpretation of Dummy Variables in Semi-logarithmic Equations", American Economic Review, Vol. 70, No. 3, pp. 474-475.

Hardell, L., Mild, K.H., Carlberg, M. (2003), "Further Aspects On Cellular and Cordless Telephones and Brain Tumors", International Journal of Oncology, Vol.22(2), pp399-407.

Hite. D, Chern, W.S., Hitzhusen, F. Randall, A. (2001), "Property Value Impacts of an Environmental Dis-amenity". Journal of Real Estate Finance and Economics, Vol.22:2/3, pp.185-202.

Kinnard, W. N., Geckler, M. B., \& Dickey, S. A. (1994), 'Fear (as a measure of damages) strikes out: two case studies comparisons of actual market behaviour 
with opinion survey research', Paper presented at The Tenth Annual American Real Estate Society Conference, April, Santa Barbara, California.

Kinnard,Jr.,W.N. DeLoittie, J.W. Geckler, M.B., Noble, B.H. (1995). ”The Impact of Widespread, Long-term Soil Contamination on Residential Property Values: A Case Study," Paper presented at the American Real Estate Society Conference, Hilton Head, South Carolina.

Michelozzi, P., Capon, A., Kirchmayer, U., Forastiere, F., Biggeri, A., Barca, A., \& Perucci, C.A. (2002), "Adult and Childhood Leukemia near a High-Power Radio Station in Rome, Italy", American Journal of Epidemiology, Vol.155, pp.10961103.

McCluskey, J.J. \& Rausser, G. C. (2000), "Stigmatized Asset Values: Is it Temporary or Permanent?" Research paper: Department of Agricultural Economics, Washington State University, WA.

Moulder, J.E., Foster, K.E., Erdreich, L.S., \& McNamee, J.P. (2005), "Mobile Phones, Mobile Phone Base Stations, and Cancer: A Review", International Journal of Radiation Biology, Vol. 81, pp.189-203.

Reichert, A.J. (1997)" Impact of a Toxic Waste Superfund Site on Property Values", The Appraisal Journal, Vol. 65, pp. 381-392.

Rosen, S. (1974), "Hedonic Prices and Implicit Markets: Product Differentiation in Pure Competition”, Journal of Political Economy, Vol. 82, pp. 34-55.

Siemens, H. (2003), "Stigma of Contaminated Land: Difficult to Tackle", The Appraisal Journal, Vol. 71, pp.121-127.

Simons, R.A. Winson-Geideman, K. and Mikelbank, B. (2001), "The Effects of an Oil Pipeline Rupture on Single-Family House Prices Along the Patuxent River in Maryland", Paper presented at The American Real Estate Society conference, April, Coeur d'Alene, Idaho.

Slovic, P. (1992), "Perceptions of risk: Reflections on the psychometric paradigm", in Social Theories of Risk, eds. S. Krimsky \& D. Golding, Praeger, Westport, Connecticut, pp. 117-152.

Strand, J. and Vagnes, M. (2001), "The Relationship Between Property Values and Railroad Proximity: A Study Based on Hedonic Prices and Real Estate Brokers' Appraisals", Transportation, Vol. 28, pp 137. 
Szmigielski, S. and Sobiczewska, E. (2000). "Cellular Phone Systems and Human Health - Problems with Risk Perception and Communication", Environmental Management and Health, Vol. 11, pp 352-368. 


\section{Appendix I- Regression Model with "TOWER"}

\begin{tabular}{|c|c|c|c|c|}
\hline Variable & Estimate & Std. Error & $\mathrm{t}$ & value $\operatorname{Pr}(>|t|)$ \\
\hline (Intercept) & $8.60 \mathrm{e}+00$ & $1.40 \mathrm{e}-01$ & 61.24 & $0.0000^{* * *}$ \\
\hline CATGYX2D & $6.66 \mathrm{e}-02$ & $2.54 \mathrm{e}-02$ & 2.62 & $0.00882 * *$ \\
\hline CATGYX2F & $-7.01 \mathrm{e}-02$ & $2.65 \mathrm{e}-02$ & -2.64 & $0.00826 * *$ \\
\hline CATGYX2R & $7.95 \mathrm{e}-02$ & $4.15 \mathrm{e}-02$ & 1.92 & 0.05546 . \\
\hline CATGYX4B & $-1.41 \mathrm{e}-01$ & $7.41 \mathrm{e}-03$ & -19.07 & $0.0000 * * *$ \\
\hline CATGYX4C & $-1.88 \mathrm{e}-01$ & $1.86 \mathrm{e}-02$ & -10.09 & $0.0000 * * *$ \\
\hline NEWAGE & $-4.22 \mathrm{e}-03$ & $1.11 \mathrm{e}-04$ & -37.95 & $0.0000 * * *$ \\
\hline $\log ($ LANDAX $)$ & $1.01 \mathrm{e}-01$ & $6.42 \mathrm{e}-03$ & 15.73 & $0.0000 * * *$ \\
\hline $\log ($ MATFAX) & $6.32 \mathrm{e}-01$ & $8.50 \mathrm{e}-03$ & 74.38 & $0.0000 * * *$ \\
\hline SLDATX1 & $2.42 \mathrm{e}-05$ & $1.74 \mathrm{e}-06$ & 13.88 & $0.0000 * * *$ \\
\hline WALLCNXB & $5.04 \mathrm{e}-02$ & $2.86 \mathrm{e}-02$ & 1.76 & 0.07768 . \\
\hline WALLCNXC & $2.05 \mathrm{e}-02$ & $2.86 \mathrm{e}-02$ & 0.72 & 0.47301 \\
\hline WALLCNXF & $-3.54 \mathrm{e}-02$ & $3.18 \mathrm{e}-02$ & -1.11 & 0.26636 \\
\hline WALLCNXG & $1.75 \mathrm{e}-01$ & $1.26 \mathrm{e}-01$ & 1.39 & 0.16527 \\
\hline WALLCNXI & $2.47 \mathrm{e}-01$ & $8.27 \mathrm{e}-02$ & 2.99 & $0.00280 * *$ \\
\hline WALLCNXO & $4.70 \mathrm{e}-02$ & $8.32 \mathrm{e}-02$ & 0.56 & 0.57268 \\
\hline WALLCNXP & $-1.94 \mathrm{e}-02$ & $3.72 \mathrm{e}-02$ & -0.52 & 0.60233 \\
\hline WALLCNXR & $2.51 \mathrm{e}-02$ & $2.88 \mathrm{e}-02$ & 0.87 & 0.38365 \\
\hline WALLCNXS & $5.03 \mathrm{e}-02$ & $3.39 \mathrm{e}-02$ & 1.49 & 0.13752 \\
\hline WALLCNXW & $4.60 \mathrm{e}-02$ & $2.85 \mathrm{e}-02$ & 1.61 & 0.10658 \\
\hline WALLCNXX & $7.78 \mathrm{e}-03$ & $3.00 \mathrm{e}-02$ & 0.26 & 0.79553 \\
\hline ROOFCNXI & $4.63 \mathrm{e}-01$ & $1.24 \mathrm{e}-01$ & 3.74 & $0.0000^{* * *}$ \\
\hline ROOFCNXO & $3.68 \mathrm{e}-01$ & $1.24 \mathrm{e}-01$ & 2.96 & $0.00311 * *$ \\
\hline ROOFCNXT & $4.26 \mathrm{e}-01$ & $1.24 \mathrm{e}-01$ & 3.44 & $0.0000^{* * *}$ \\
\hline SUBURBAvonhe & $-2.61 \mathrm{e}-01$ & $1.07 \mathrm{e}-02$ & -24.26 & $0.0000 * * *$ \\
\hline SUBURBBromle & $-5.94 \mathrm{e}-01$ & $1.13 \mathrm{e}-02$ & -52.32 & $0.0000 * * *$ \\
\hline SUBURBBeckenham & $-4.05 e-01$ & $9.09 \mathrm{e}-03$ & -44.56 & $0.0000 * * *$ \\
\hline SUBURBBishop & $-3.66 \mathrm{e}-01$ & $1.07 \mathrm{e}-02$ & -34.32 & $0.0000 * * *$ \\
\hline SUBURBIlam & $-1.65 \mathrm{e}-01$ & $1.18 \mathrm{e}-02$ & -13.94 & $0.0000^{* * *}$ \\
\hline SUBURBPapanui & $-4.37 e-01$ & $9.94 \mathrm{e}-03$ & -44.01 & $0.0000 * * *$ \\
\hline SUBURBLinwoo & $-6.05 \mathrm{e}-01$ & $1.08 \mathrm{e}-02$ & -55.80 & $0.0000^{* * *}$ \\
\hline SUBURBUpRic & $-2.09 \mathrm{e}-01$ & $1.07 \mathrm{e}-02$ & -19.52 & $0.0000 * * *$ \\
\hline SUBURBSpreyd & $-4.54 \mathrm{e}-01$ & $1.05 \mathrm{e}-02$ & -43.05 & $0.0000 * * *$ \\
\hline TOWER & $-2.29 \mathrm{e}-02$ & $8.72 \mathrm{e}-03$ & -2.62 & $0.00880 * *$ \\
\hline \multicolumn{5}{|c|}{$\begin{array}{l}\text { Signif. codes: } 0{ }^{\prime * * * 1} 0.001^{` * * \prime} 0.01^{` *} 0.055^{\prime}{ }^{\prime} 0.1^{`}{ }^{\prime} 1 \\
\text { Residual standard error: } 0.173 \text { on } 8659 \text { degrees of freedom } \\
\text { Multiple R-Squared: } 0.835, \quad \text { Adjusted R-squared: } 0.834 \\
\text { F-statistic: } 1.33 \mathrm{e}+03 \text { on } 33 \text { and } 8659 \mathrm{DF}, \text { p-value: }<2 \mathrm{e}-16\end{array}$} \\
\hline
\end{tabular}




\section{Appendix II - Regression Model with "inv.dist"}

\begin{tabular}{|c|c|c|c|c|}
\hline Variable & Estimate & Std. Error & t value & $\operatorname{Pr}(>|\mathrm{t}|)$ \\
\hline (Intercept) & $8.65 \mathrm{e}+00$ & $1.42 \mathrm{e}-01$ & 61.06 & $0.0000^{* * *}$ \\
\hline CATGYX2D & $6.40 \mathrm{e}-02$ & $2.57 \mathrm{e}-02$ & 2.49 & $0.01268 *$ \\
\hline CATGYX2F & $-7.49 \mathrm{e}-02$ & $2.68 \mathrm{e}-02$ & -2.80 & $0.00517 * *$ \\
\hline CATGYX2R & $8.32 \mathrm{e}-02$ & $4.19 \mathrm{e}-02$ & 1.99 & $0.04687 *$ \\
\hline CATGYX4B & $-1.45 \mathrm{e}-01$ & $7.46 \mathrm{e}-03$ & -19.46 & $0.0000^{* * *}$ \\
\hline CATGYX4C & $-2.02 \mathrm{e}-01$ & $1.87 \mathrm{e}-02$ & -10.79 & $0.0000^{* * *}$ \\
\hline NEWAGE & $-4.19 \mathrm{e}-03$ & $1.12 \mathrm{e}-04$ & -37.38 & $0.0000^{* * *}$ \\
\hline $\log ($ LANDAX $)$ & $1.01 \mathrm{e}-01$ & $6.46 \mathrm{e}-03$ & 15.60 & $0.0000 * * *$ \\
\hline $\log ($ MATFAX) & $6.24 \mathrm{e}-01$ & $8.52 \mathrm{e}-03$ & 73.23 & $0.0000^{* * *}$ \\
\hline SLDATX1 & $2.41 \mathrm{e}-05$ & $1.70 \mathrm{e}-06$ & 14.17 & $0.0000 * * *$ \\
\hline WALLCNXB & $5.19 \mathrm{e}-02$ & $2.88 \mathrm{e}-02$ & 1.80 & 0.07216 . \\
\hline WALLCNXC & $2.19 \mathrm{e}-02$ & $2.88 \mathrm{e}-02$ & 0.76 & 0.44817 \\
\hline WALLCNXF & $-3.39 \mathrm{e}-02$ & $3.21 \mathrm{e}-02$ & -1.06 & 0.29112 \\
\hline WALLCNXG & $1.78 \mathrm{e}-01$ & $1.28 \mathrm{e}-01$ & 1.40 & 0.16180 \\
\hline WALLCNXI & $1.13 \mathrm{e}-02$ & $7.72 \mathrm{e}-02$ & 0.15 & 0.88380 \\
\hline WALLCNXO & $4.83 \mathrm{e}-02$ & $8.40 \mathrm{e}-02$ & 0.58 & 0.56530 \\
\hline WALLCNXP & $-1.05 e-02$ & $3.76 \mathrm{e}-02$ & -0.28 & 0.78084 \\
\hline WALLCNXR & $2.46 \mathrm{e}-02$ & $2.91 \mathrm{e}-02$ & 0.84 & 0.39849 \\
\hline WALLCNXS & $5.20 \mathrm{e}-02$ & $3.42 \mathrm{e}-02$ & 1.52 & 0.12774 \\
\hline WALLCNXW & $4.68 \mathrm{e}-02$ & $2.88 \mathrm{e}-02$ & 1.63 & 0.10371 \\
\hline WALLCNXX & $1.03 \mathrm{e}-02$ & $3.03 e-02$ & 0.34 & 0.73478 \\
\hline ROOFCNXI & $4.54 \mathrm{e}-01$ & $1.25 \mathrm{e}-01$ & 3.64 & $0.0000^{* * *}$ \\
\hline ROOFCNXO & $3.59 \mathrm{e}-01$ & $1.26 \mathrm{e}-01$ & 2.86 & $0.00425 * *$ \\
\hline ROOFCNXT & $4.18 \mathrm{e}-01$ & $1.25 \mathrm{e}-01$ & 3.34 & $0.0000 * * *$ \\
\hline SUBURBAvonhe & $-2.58 \mathrm{e}-01$ & $1.04 \mathrm{e}-02$ & -24.85 & $0.0000 * * *$ \\
\hline SUBURBBromle & $-5.91 \mathrm{e}-01$ & $1.10 \mathrm{e}-02$ & -53.87 & $0.0000 * * *$ \\
\hline SUBURBBeckenham & $-4.04 \mathrm{e}-01$ & $8.84 \mathrm{e}-03$ & -45.68 & $0.0000 * * *$ \\
\hline SUBURBBishop & $-3.64 \mathrm{e}-01$ & $1.03 \mathrm{e}-02$ & -35.21 & $0.0000 * * *$ \\
\hline SUBURBIlam & $-1.61 \mathrm{e}-01$ & $1.15 \mathrm{e}-02$ & -14.01 & $0.0000^{* * *}$ \\
\hline SUBURBPapanui & $-4.36 \mathrm{e}-01$ & $9.68 \mathrm{e}-03$ & -44.98 & $0.0000 * * *$ \\
\hline SUBURBLinwoo & $-6.05 e-01$ & $1.05 \mathrm{e}-02$ & -57.74 & $0.0000^{* * *}$ \\
\hline SUBURBUpRic & $-2.05 \mathrm{e}-01$ & $1.03 \mathrm{e}-02$ & -19.88 & $0.0000^{* * *}$ \\
\hline SUBURBSpreyd & $-4.51 \mathrm{e}-01$ & $1.01 \mathrm{e}-02$ & -44.46 & $0.0000 * * *$ \\
\hline inv.dist & $-3.68 \mathrm{e}-01$ & $1.39 \mathrm{e}-01$ & -2.64 & $0.00821 * *$ \\
\hline \multicolumn{5}{|c|}{ 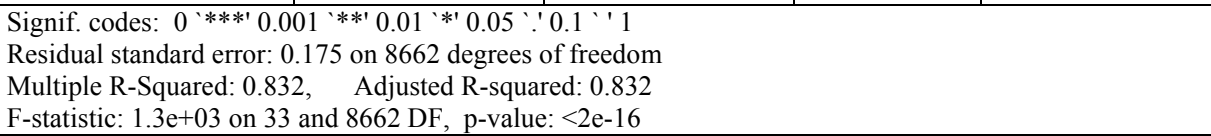 } \\
\hline
\end{tabular}




\section{Appendix III - Regression Model with "DIST"}

\begin{tabular}{|c|c|c|c|c|}
\hline Variable & Estimate & Std. Error & t values & $\operatorname{Pr}(>|t|)$ \\
\hline (Intercept) & $8.61 \mathrm{e}+00$ & $1.40 \mathrm{e}-01$ & 61.29 & $0.0000 * * *$ \\
\hline CATGYX2D & $6.68 \mathrm{e}-02$ & $2.54 \mathrm{e}-02$ & 2.63 & $0.00865 * *$ \\
\hline CATGYX2F & $-6.95 e-02$ & $2.65 \mathrm{e}-02$ & -2.62 & $0.00882 * *$ \\
\hline CATGYX2R & $7.67 \mathrm{e}-02$ & $4.15 \mathrm{e}-02$ & 1.85 & 0.06470 \\
\hline CATGYX4B & $-1.41 \mathrm{e}-01$ & $7.41 \mathrm{e}-03$ & -19.05 & $0.0000 * * *$ \\
\hline CATGYX4C & $-1.88 \mathrm{e}-01$ & $1.86 \mathrm{e}-02$ & -10.10 & $0.0000 * * *$ \\
\hline NEWAGE & $-4.23 e-03$ & $1.11 \mathrm{e}-04$ & -38.05 & $0.0000^{* * *}$ \\
\hline $\log ($ LANDAX) & $1.00 \mathrm{e}-01$ & $6.42 \mathrm{e}-03$ & 15.61 & $0.0000^{* * *}$ \\
\hline $\log$ (MATFAX) & $6.32 \mathrm{e}-01$ & $8.49 \mathrm{e}-03$ & 74.36 & $0.0000 * * *$ \\
\hline SLDATX1 & $2.40 \mathrm{e}-05$ & $1.74 \mathrm{e}-06$ & 13.77 & $0.0000 * * *$ \\
\hline WALLCNXB & $4.66 \mathrm{e}-02$ & $2.86 \mathrm{e}-02$ & 1.63 & 0.10266 \\
\hline WALLCNXC & $1.67 \mathrm{e}-02$ & $2.86 \mathrm{e}-02$ & 0.58 & 0.56016 \\
\hline WALLCNXF & $-3.98 \mathrm{e}-02$ & $3.18 \mathrm{e}-02$ & -1.25 & 0.21109 \\
\hline WALLCNXG & $1.73 \mathrm{e}-01$ & $1.26 \mathrm{e}-01$ & 1.37 & 0.17016 \\
\hline WALLCNXI & $2.52 \mathrm{e}-01$ & $8.27 \mathrm{e}-02$ & 3.05 & $0.00233 * *$ \\
\hline WALLCNXO & $4.88 \mathrm{e}-02$ & $8.32 \mathrm{e}-02$ & 0.59 & 0.55760 \\
\hline WALLCNXP & $-1.86 \mathrm{e}-02$ & $3.75 \mathrm{e}-02$ & -0.50 & 0.62047 \\
\hline WALLCNXR & $2.10 \mathrm{e}-02$ & $2.88 \mathrm{e}-02$ & 0.73 & 0.46684 \\
\hline WALLCNXS & $4.48 \mathrm{e}-02$ & $3.39 \mathrm{e}-02$ & 1.32 & 0.18606 \\
\hline WALLCNXW & $4.32 \mathrm{e}-02$ & $2.85 \mathrm{e}-02$ & 1.52 & 0.12979 \\
\hline WALLCNXX & $5.34 \mathrm{e}-03$ & $3.00 \mathrm{e}-02$ & 0.18 & 0.85876 \\
\hline ROOFCNXI & $4.62 \mathrm{e}-01$ & $1.24 \mathrm{e}-01$ & 3.73 & $0.0000 * * *$ \\
\hline ROOFCNXO & $3.67 \mathrm{e}-01$ & $1.24 \mathrm{e}-01$ & 2.95 & $0.00323 * *$ \\
\hline ROOFCNXT & $4.25 \mathrm{e}-01$ & $1.24 \mathrm{e}-01$ & 3.44 & $0.0000 * * *$ \\
\hline SUBURBAvonhe & $-2.59 \mathrm{e}-01$ & $1.08 \mathrm{e}-02$ & -24.12 & $0.0000 * * *$ \\
\hline SUBURBBromle & $-5.93 e-01$ & $1.14 \mathrm{e}-02$ & -52.21 & $0.0000 * * *$ \\
\hline SUBURBBeckenham & $-4.02 \mathrm{e}-01$ & $9.12 \mathrm{e}-03$ & -44.11 & $0.0000 * * *$ \\
\hline SUBURBBishop & $-3.63 e-01$ & $1.07 \mathrm{e}-02$ & -33.98 & $0.0000 * * *$ \\
\hline SUBURBIlam & $-1.64 \mathrm{e}-01$ & $1.18 \mathrm{e}-02$ & -13.84 & $0.0000 * * *$ \\
\hline SUBURBPapanui & $-4.37 \mathrm{e}-01$ & $9.95 \mathrm{e}-03$ & -43.90 & $0.0000 * * *$ \\
\hline SUBURBLinwoo & $-6.04 \mathrm{e}-01$ & $1.09 \mathrm{e}-02$ & -55.65 & $0.0000 * * *$ \\
\hline SUBURBUpRic & $-2.08 \mathrm{e}-01$ & $1.07 \mathrm{e}-02$ & -19.42 & $0.0000 * * *$ \\
\hline SUBURBSpreyd & $-4.52 \mathrm{e}-01$ & $1.05 \mathrm{e}-02$ & -42.88 & $0.0000 * * *$ \\
\hline DIST1 & $-2.78 \mathrm{e}-02$ & $1.20 \mathrm{e}-02$ & -2.32 & $0.02030 *$ \\
\hline DIST2 & $-2.91 \mathrm{e}-02$ & $1.06 \mathrm{e}-02$ & -2.73 & $0.00630 * *$ \\
\hline DIST3 & $-3.98 \mathrm{e}-03$ & $1.15 \mathrm{e}-02$ & -0.35 & 0.73008 \\
\hline \multicolumn{5}{|c|}{ 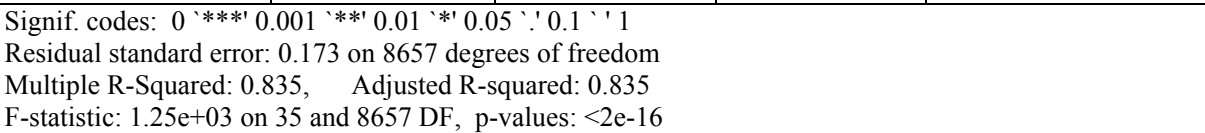 } \\
\hline
\end{tabular}

